tees. For example, during the last session one clerk supervised the sub-committees dealing with Space Research and Development and the workings of the Industrial Training Act, as well as the Joint Committee on Censorship of the Theatre. It is impossible to expect one man to be an expert in three such diverse fields, but as long as the Treasury controls the purse-strings and can treat the House as "a subordinate Government department", to use Sir Barnett's phrase, the situation seems unlikely to change.

Recruitment is also a problem. There have for the past few years always been one or two vacancies for clerks and at present there are four. Clerks are only recruited by the Civil Service Commission's administrative grade examination; candidates must designate the House of Commons as their first choice and are expected to serve the House for the whole of their professional working life - forty years before they are eligible for a pension. At present, the House of Commons is at a grave disadvantage for, on average, promotion prospects lag ten years behind those of the Civil Service proper. Sir Barnett said "this is the greatest single factor in discouraging recruitment".

In the decision on May 20, Dr David Owen brought up a problem relating specifically to the Science and Technology Committee-the need for a clerk with a scientific background. Without casting aspersions on the hard work of the committee's present clerk, he felt that a trained scientist who was able to build up an expertise in the field would be of invaluable help to the committee. Sir Barnett rejected any possibility of recruiting a trained scientist from outside the Civil Service Commission on the grounds that it would be "destructive of morale" to other clerks who had risen through the ranks over the years. He added that "in theory I could recruit anyone at all on my own initiative, but in practice I would always refuse to recruit from any other source [than the Civil Service]".

\section{Defending Defence}

Sir Willtam Cook, Chief Adviser (Projects and Research) for the Ministry of Defence, defended himself and his ministry quite ably before the Select Committee on Science and Technology on June 20. Referring to joint projects with other countries, he admitted that there were many drawbacks; administrative machinery was increased and the total cost was usually about 10 to 15 per cent higher. None the less, because each country's share was much lower than if it was working independently, the Government believed the advantages outweighed the disadvantages.

Sir William said that he could not comment on the many cancelled projects of the ministry - such as the TSR2-because these decisions had been made before he took up his post, but he did suggest that the ministry's machinery for assessing projects was steadily improving. As they become more sure of the viability of projects before starting them, the risk of cancellation is decreased. Many of the ministries, the Ministry of Technology especially, are trying to encourage a system in which managers take control of particular projects. This will take time, however, for, as Sir William said, "The Civil Service is not used to individuals making decisions". There has been a great increase in the past few years in courses for project managers, but the present method of training managers, Sir William said, is to start them on small projects and move them gradually to big ones, a slow and not entirely satisfactory arrangement.

Sir William bemoaned the fact that it was still impossible for scientists to move freely between industry and government research establishments. He himself wanted to see a completely free market between the two with complete interchange of pension schemes, but saw little hope of this happening in the near future.

\section{Costly Airbus}

THE European airbus project, which only a month ago seemed well set, has now run into more trouble. For one thing, Mr John Stonehouse, Minister of State at the Ministry of Technology, has got around to admitting to the House of Commons that the cost of the project has increased sharply, from $£ 190$ million to $£ 285$ million. This should have come as no surprise, for the Federal German Government admitted as much some weeks ago. It turns out that the engines, which were to cost $£ 60$ million, will in fact run to $£ 70$ million and the airframe, originally priced at $£ 130$ million, will now cost $£ 215$ million. Connoisseurs of aircraft costing will no doubt regard this as no more than a foretaste of what is to come, because Mr Stonehouse said that the figures were subject to further negotiation. Aircraft costs rarely go down with negotiation.

As usual on occasions like this, the increased costs can be attributed, in part at least, to changes in specification. The airlines asked for more powerful RollsRoyce $R B 207$ engines and heavier internal equipment. But devaluation has also played a part, according to Mr Stonehouse. The increase in costs, together with a distinctly lukewarm attitude on the part of some airlines-notably Lufthansa-must now put the project in jeopardy. The ministers concerned from France, UK and Germany will be meeting next month for further discussion, and the future of the project will depend on the airlines ordering at least 75 airbuses. With coolness from Germany, economic trouble in France, and the distinct danger of further financial travail for Britain, it cannot be said to be a very cheerful prospect. Meanwhile Boeing has begun work on an airbus design which bears some striking resemblances to the European airbus.

\section{Matrons Scorned}

THE resignation of two matrons within a short space of time suggests that discontent among hospital staff is on the increase. It was announced last week that Miss Marian Smith, matron of Stepping Hill Hospital, Stockport, had resigned because of lack of confidence in the administration of the hospital. This follows the resignation of Miss A. Johnson, matron of Guy's Hospital, nearly three weeks ago.

These two events seem to stem from the same cause matrons simply do not wield today the power they used to. Together with senior nurses they are assuming more and more responsibility, but their opinions are not being taken into account. It would not be a gross exaggeration to say that the concept of an all-powerful, dictatorial matron is fast disappcaring, and this is perhaps no bad thing, because no individual can successfully carry the burden of running a hospital. 
But the answer does not lie in the appointment of honorary members of hospital committees who may be highly capable managers and administrators in their own right, but who have no real knowledge of the problems of nursing staff. What seems to be happening is that these "amateurs"-Lord Robens is said to be no exception here-are overriding the people with professional knowledge.

The matron's lot is certainly not an easy one; although she is no longer responsible for catering and other domestic affairs, her responsibility for staffing the wards is greater. Recent achievements in medicine, such as dialysis units, transplantation units and the like, demand more nurses per porson than ever before, at the expense of ward staff. And as nurses are working shorter hours, the demand for more nurses increases. This difficulty is increased by the fact that a matron has a much more complicated staffing pattern to control, because she has to rely on part-time nurses and married staff. In addition, she has somehow to try to maintain a balance between the disproportionate number of trainee nurses and tutors, which adds to the confusion.

Recent reports have looked at the pattern of management primarily from the independent points of view of the nurse, the doctor and the administrator. But the hospital is an integrated whole, and until it has been studied as such by a suitably qualified team the present state of uncertainty seems likely to continue. Admittedly the main recommendation of the Salmon report seems to be a move in the right direction: this was that a new post should be created - that of chief nursing officer or "super matron" who would parallel the senior hospital lay administrator and who would advise and make recommendations to the management on nursing matters. So far, twenty of these Salmon pilot schemes have been put into action up and down the country and, perhaps surprisingly, the post can be filled by either a man or a woman. The principal resistance to male nurses seems to come in fact, from the male administrators themselves. The way the scheme works is that the matron looks after day-to-day decisions, leaving the chief nursing officer to concentrate on overall policy and to plan future development. Whether this will improve relations and lead to more balanced administration remains to be seen.

\section{Modest Oxford}

AN implicit rejection of some of the targets set by the report of the Franks Commission has now been published at Oxford. It is in the form of a report published by a committee which included among its members the Vice-Chancellor, Mr Alan Bullock, and five others. The committee was set up by the Council and the General Board of the university, which have now published the report for discussion in the conference of colleges and in Congregation next term.

The main argument in the report is that it will be impossible for a variety of reasons for the university to achieve the student numbers recommended by Franks. His commission suggested that the university might aim to increase from its present size of just over 10,000 students to about 13,000 over the next fifteen to twenty years. The increase would have been made up of 8,750 undergraduates $(5,000$ to 5,500 in arts and social studies, and 3,250 to 3,750 in science and medi- cine), 3,750 graduates and 500 students in vocational or professional courses. The new report points out that an increase of this order would involve an overall increase in the Oxford population of between 9,000 and 10,000 , when families, ancillary staff and extra provision for schools and transport and the like are taken into account. Only 2,450 of these, according to the Oxford City Architect, could be regarded as covered by the eity development plan.

Considerations like these, and the feeling that university finance is likely to be rather harder to come by in the next five years, have led the committee to recommend a total figure of 10,775 students as an absolute maximum for 1971-72. In the five years after that, the committee says, the number should increase, but only to 11,500 . The feeling conveyed by the report is that Oxford could not absorb more new students than this without in some way changing the character of the place. Residential accommodation will obviously be a problem, as there is little space in central Oxford for more building, and the idea of producing a second campus on the fringe of Oxford is anathema. Lodgings for students are also becoming harder to find, and the report concludes by saying that, despite the modest expansion foreseen, there may nevertheless be little room for expansion after 1977. But, as the committee wisely admits, such a conclusion might have been reached at many periods in the pastindeed as recently as the fifties. It would in the committee's opinion be unwise to fix numbers at 11,500 for all time. Further expansion may be possible.

Within the small expansion, the committee sees a need for more women at Oxford. Unfortunately for the men, women will still be a tiny minority, howeveran increase from less than 1,400 now to some 1,575 by 1977 is proposed. This, lonely men are bound to feel, is a less than dramatic improvement in their fortunes.

\section{Memo on Libraries}

THE Library Association has reaffirmed its view that the library departments of the British Museum should be administered separately from the antiquities departments, and that there should be a National Library Service. In its memorandum of evidence to the National Libraries Committee, published in the latest issue of the Library Association Record (190, 154; June 1968) the association suggests that a National Library Service, under the direction of a professionally experienced director-general, be made up from the library departments of the British Museum, the National Central Library, the National Lending Library for Science and Technology and the British National Bibliography and Copyright Offices. There should also be a new National Bibliographical and Information Service.

The association recommends that the National Library Service should be in two principal divisionsthe National Reference Library and the National Lending Library. The reference section would be sited in central London and would cover all subjects. Although no definite statement is made about the location of the reference library, the association implies that the British Museum site would be the best- "the site area of 7.5 acres envisaged by the British Museum trustees would not appear to be excessive". The book stock of the lending library would be formed from the 